Abstracta Iranica Abstracta Iranica

Revue bibliographique pour le domaine irano-aryen

Volume 31 | 2011

Comptes rendus des publications de 2008

« Le Caire, Istanbul, Téhéran : trois mégapoles, une dynamique? ». Travaux de l'Institut de Géographie de Reims, 127-128, vol. 32, 2006 [paru déc. 2008], p. 9-40.

Rédaction

\title{
OpenEdition
}

Journals

Édition électronique

URL : http://journals.openedition.org/abstractairanica/39829

DOI : 10.4000/abstractairanica.39829

ISSN : 1961-960X

Éditeur :

CNRS (UMR 7528 Mondes iraniens et indiens), Éditions de l'IFRI

Édition imprimée

Date de publication : 15 mai 2011

ISSN : 0240-8910

Référence électronique

Rédaction, « « Le Caire, Istanbul, Téhéran : trois mégapoles, une dynamique ? ». Travaux de l'Institut de Géographie de Reims, 127-128, vol. 32, 2006 [paru déc. 2008], p. 9-40. », Abstracta Iranica [En ligne], Volume 31 | 2011, document 303, mis en ligne le 11 octobre 2012, consulté le 26 septembre 2020. URL : http://journals.openedition.org/abstractairanica/39829; DOI : https://doi.org/10.4000/ abstractairanica.39829

Ce document a été généré automatiquement le 26 septembre 2020.

Tous droits réservés 


\section{« Le Caire, Istanbul, Téhéran : trois mégapoles, une dynamique?». Travaux de l'Institut de Géographie de Reims, 127-128, vol. 32, 2006 [paru déc. 2008], p. 9-40.}

\section{Rédaction}

Rédigée par trois géographes à partir de travaux de terrain, cette analyse de géographie comparée est très documentée et propose un bilan comparé original des trois mégapoles du Moyen-Orient: Le Caire, Istanblul et Téhéran. Les AA. mettent en évidence les dynamiques communes (stabilisation démographique mais expansion spatiale, éclatement des centralités, déclin des zones centrales, extension des périphéries, disparités socio-spatiales accentuées, dégradation de l'environnement, problèmes de gouvernance) et les identités spécifiques. La place de chacune des mégapoles dans la mondialisation est ainsi très différente entre Istanbul de plus en plus ouvert sur l'Europe mais aussi vers la Russie et le Moyen-Orient et Téhéran simple capitale nationale, coupée du reste du monde, sans dynamique internationale, tandis que Le Caire cède sa place de pôle dominant la région. On regrettera que les cartes soient peu explicites.

\section{INDEX}

Thèmes : 15.1. Iran 


\section{AUTEURS}

\section{RÉDACTION}

Directeur de la revue et secrétariats (Paris et Téhéran) 